\title{
Retraction: On soft expert topological spaces
}

\author{
Sabir Hussain ${ }^{1 *}$ and Mohammad Ahmad Alghamdi ${ }^{2}$
}

After publication of article [1], we became aware of the fact that sections of this article were taken verbatim without quotation from [2] and [3] listed below. In addition, 'example 2' and 'algorithm 4.1' as presented in this article are identical to 'example 3.3' from [3] and 'algorithm 4.1' from [2]. In light of these problems and in consultation with the journal's Section Editor for Mathematics we have decided to retract this article from SpringerPlus.

\section{Author details}

${ }^{1}$ Department of Mathematics, Yanbu University, P. O. Box 31387, Yanbu Alsinaiyah, Saudi Arabia. ${ }^{2}$ Department of Mathematics, King Abdul Aziz University, P. O. Box 80203, Jeddah 21589, Saudi Arabia.

Received: 30 June 2012 Accepted: 20 August 2012

Published: 24 October 2012

\section{References}

1. Hussain S (2012) On soft expert topological spaces. SpringerPlus 1:42. doi:10.1186/2193-1801-1-42. Published: 24 October 2012

2. Alkhazaleh S, Salleh AR (2011) Soft Expert Sets. Adv Decis Sci 2011. doi:10.1155/2011/757868. Article ID 757868

3. Shabir M, Naz M (2011) On soft topological spaces. Comput Math Appl 61 (7):1786-1799. doi:10.1016/j.camwa.2011.02.006

\footnotetext{
* Correspondence: sabiriub@yahoo.com

${ }^{1}$ Department of Mathematics, Yanbu University, P. O. Box 31387, Yanbu Alsinaiyah, Saudi Arabia

Full list of author information is available at the end of the article
}

Submit your manuscript to a SpringerOpen ${ }^{\circ}$ journal and benefit from:

- Convenient online submission

Rigorous peer review

- Immediate publication on acceptance

- Open access: articles freely available online

- High visibility within the field

- Retaining the copyright to your article

Submit your next manuscript at $>$ springeropen.com

\section{Springer}

(c) 2012 Hussain and Alghamdi; licensee Springer. This is an Open Access article distributed under the terms of the Creative Commons Attribution License (http://creativecommons.org/licenses/by/2.0), which permits unrestricted use, distribution, and reproduction in any medium, provided the original work is properly cited. 